\title{
Impact of International Outsourcing on Domestic Wage of Singapore Manufacturing Sector
}

\author{
Sandip Chakraborty ${ }^{1}$, Ram Kumar Kakani ${ }^{2} \&$ Bernadette C. Canasa ${ }^{3}$ \\ ${ }^{1}$ Domain Consultant (Statistics), Tata Consultancy Services, India \\ ${ }^{2}$ Professor, XLRI Xavier School of Management, Jamshedpur, India \\ ${ }^{3}$ Project Manager, SCSI Singapore Pte., USA \\ Correspondence: Ram Kumar Kakani, XLRI Xaviers School of Management, Jamshedpur, Jharkhand -831001, \\ India. Tel: 91-657-665-3104. E-mail: kakani@xlri.ac.in
}

Received: April 6, 2017

Accepted: April 22, 2017

Online Published: May 15, 2017

doi:10.5539/ijef.v9n6p82

URL: https://doi.org/10.5539/ijef.v9n6p82

\begin{abstract}
This study focuses on measuring the extent of international outsourcing across Singapore manufacturing sector and the impact on domestic wages of workers. Based on the framework of Feenstra and Hanson (1999), this study measured the narrow and wide outsourcing from the overseas intermediate imports. In estimating the impact of international outsourcing on wage, this study reviews the model developed by Geishecker and Görg (2008) and modifies the same by incorporating the parametric stability approach of Hamilton's (1989) Markov Switching model. Results after incorporating the nonlinearity, indicates that outsourcing dynamics can be better understood through modified framework developed.
\end{abstract}

Keywords: international trade, outsourcing, Singapore, manufacturing, domestic wages, switching regression models

\section{Introduction and Literature Review}

Trade liberalization has changed the way of doing business from local dependency to global. Traditionally, manufacturers used to rely heavily on internal local production processes for the manufacturing of goods. As the market needs change, consumer goods require constant innovation and cost competitiveness. To advance economic growth, Governments tie up with other countries and opens opportunities for lower trade barriers. Manufacturing firms take advantage of the open economy by obtaining the efficient way of producing goods internationally. They have the opportunity to source out external supply of materials, components and parts from low-cost manufacturer or to obtain highly technological materials from different suppliers.

Against this backdrop of trade liberalization, international outsourcing and subcontracting activities gained increased research focus in recent decades. Glass and Saggi (2001) concluded that the impact of international outsourcing affects the welfare of importing firm as it lowers the relative wage of workers which can be offset by the positive effect from faster innovation. Various studies (say, Dyer \& Ouchi, 1993; Gilley \& Rasheed, 2000) reiterated that outsourcing based on cost leadership have proven to be a big success. This growing importance of international outsourcing and its successive inclusion in various decision models both at micro and macro level has led to a stream of theoretical and empirical researches.

The connectivity of manufacturing strategy to outsourcing has been discussed in the decision framework of Dekkers (2000). Adding further to decision framework and strategy, Kumar et al. (2008) have examined the total cost of international outsourcing by developing a closed loop sourcing decision model for effective manufacturing strategy. Bertrand and Sridharan (2001) contributed further, enriching the framework by developing four-heuristic decision rules with varying informational needs and complexity to determine when and which orders should be subcontracted, limiting the focus to operational decisions. Chen and HungAn (2010) have presented an integrated fuzzy approach for selecting a suitable outsourcing manufacturing partner in pharmaceutical R\&D based on the determined weights of criteria and sub-criteria such as financial considerations, quality, service performance, compliance, environmental health \& safety compliance, and culture.

The decision framework of outsourcing and linking it to manufacturing strategy has been discussed not only on 
macro level but also at firm level. For example, Holl et al. (2010), have studied on firm level in the electronics and automotive industry the subcontracting linkages in Just-In-Time (JIT) manufacturing system and determinants of geographical extent. Using multivariate probit model, the study found that JIT has significant positive influence on probability of subcontracting locally. Business entities are likely to outsource at the local level for goods of low added value while high value added, complex goods, by contrast, appear to be outsourced in extra-regional location, such as entities engaged in technology networking. Thus, the spatial organization of a corporate entity is closely related to modes of production organization.

Along with the micro level relationship based learning's and economic benefits observed by Holl et al. (2010), typification of outsourcing or mode of outsourcing has also been found to be playing an important role in transferring the benefits of outsourcing to economic profit. For example, Bengtsson et al. (2009) found that outsourcing represents a trade-off between improving innovation capability and lowering the cost. The study also showed that manufacturing and supplier integration in product design processes is beneficial when applying innovation-oriented outsourcing, and particularly at complex manufacturing processes.

Amidst evidences of various benefits of outsourcing that have led to the development of various decision making frameworks there have also emerged a parallel stream of researches as on the potential consequences of firm or sector being engaged in increased outsourcing on the wage structure of skilled and unskilled labors. Houseman (2007) found evidence that has shown rapid growth of outsourcing in the United States has not been accompanied by widespread improvement of American worker's wage. Moreover, productivity improvements from international outsourcing may largely measure cost savings, not improvements in output per hour worked by American labor. Several researchers have attempted to trace this particular impact of outsourcing in different periods and across different spatial contexts.

Wood (1995) has contributed to the debate about the trade being the main contributor to the deteriorating situation of unskilled worker in the developed countries through substitutability of unskilled workers in a situation where factor endowments (for example, new technology factors) are generated because of trading activity. Supporting theories from Feenstra (1998), explained that globalization through international outsourcing of intermediate inputs has implication in wage inequality through the reduction of relative demand for unskilled labor of developing countries. Feenstra (1998) illustrated that increase in outsourcing activity in 1980s was contributed by the development of communication technology, thus they are complementary rather than competing factor in explaining the change in employment and wage inequality. Wood (1995) observed that increase in trade openness of developing countries has widened the wage gap between skilled and unskilled worker in East Asia during 1960s and 1970s thereby contradicting the convention that the impact has been supposed to be otherwise, i.e., decline in wage inequality through increase in demand for both skilled and unskilled labors. He attributed such relation as the outcome of increased participation of China and other low-income Asian countries into the world market for trade of labor intensive goods. Similar findings are documented in Katz and Murphy (1992) who found increasing trend of wage gap after studying supply and demand factors relative to wage changes covering the period 1963-87. The long term growth in the demand for labor through change in allocation of labor between industries and occupations has been concluded to be the driving force in wage structure.

With this behavior of widening wage gap at the onset of increased trading activity seems critical to a research attention as noted by Geishecker (2008), who postulated that international outsourcing would gather more negative impact for manual workers due to the eastern enlargement of Europe in the light of growing world market integration. In terms of behavior of equilibrium in this context involving heterogonous firms, trade has been opined to likely to contribute in higher average profits, higher unemployment and larger wage dispersion (Egger \& Kreickemeier, 2008). Egger and Stehrer (2003) showed the significant impact of outsourcing (through trade of intermediate goods with) on the change of skilled-to-unskilled wage bill ratio in Hungary, the Czech Republic and Poland, which was more pronounced in the exports of intermediate goods than for imports. However, Falk and Koebel (2002) presented different view in the relationship of demand for labor and factor endowments after examining the effects of imports of material and services on labor demand through estimating a factor demand system based on Box-Cox cost functions. The results showed that output and capital growth have more significant impact in the demand of heterogeneous labor as compared to substitution of material and services inputs. Furthermore, output growth stems from the substitution of material and services inputs rather than substitution of input induced imported materials and services. Based on the typification of outsourcing, however, Falk and Wolfmayr (2008) observed that the narrowly defined outsourcing of intermediate materials from China and the East Asian countries appeared to have a relatively small negative impact on the demand for labor as compared to those from Central and East European countries. In addition to this Munch and Skaksen 
(2005) have observed asymmetric roles played by domestic and foreign outsourcing with reference to Danish labor market data. Foreign outsourcing has a positive impact on the wages of workers with high education and negative impact on workers with vocational education. In contrast, domestic outsourcing has a positive impact on wages for workers with vocational educations while it has no impact on wages of workers with high education. Arbache et al. (2004) has shown that an increase in degree of trade openness substantially lowered the wages of traded sector on lower education groups and insignificant for those in top two education groups within sectors in Brazil. Ho et al. (2004) has also found an evidence of widening wage gap in Hong Kong labor force through the increase in trade with China. There was a positive impact on wages for well-educated workers and a negative impact for less-educated workers during the period of 1991-2000.

Feenstra and Hanson (1999) looked into the technological changes in its role in determination of wage gap. Their results suggested that both outsourcing and capital upgrading contributed to rising wage inequality in the US during the 1980's. They estimated the relative influence of technology twice as large as outsourcing on relative wages of nonproduction worker in a setting where technological change affects product prices.

Transnational corporations have restructured their operations by increasingly subcontracting. Recently, Anner (2011) have examined the impact of international outsourcing on the unionization and wages in apparel export sector in Central America. They find that horizontal dispersion of production facilities weakens labor's positional power in manufacturing, further hindering its ability to push for better wages. Segmentation has also increased labor costs as a percentage of total costs in the subcontractors while reducing sunk investment costs. This move had induced subcontractors and vendors to keep wages low and deter unionization through plant mobility.

In the context of Singapore, since the late 13th century of the Old harbor settlement, international trading in Singapore becomes a significant activity because of its geographical location and free port policy from British rule. From becoming a trading host to over 600 other ports in 123 countries, Singapore moves to bringing in raw materials and re-exporting after processing as host country to USA, Japan, and Europe. According to Lloyd and Sandilands (1986), domestic exports have high import content, netting it out showed that in 1980 around three-quarters of the value of domestic exports were the value of imported components, materials and other inputs. Later work by Hoon and Ho (2001), reported that import requirement made up to $60 \%$ of the total value of export of goods and services in 1990. Moreover, the percentage of imported intermediate inputs in manufacturing was reported to be at $80 \%$. Hoon and Ho (2001) have also highlighted the role of multinational corporations as the main driver of cross-border activities in Singapore in the changing pattern of production fragmentation.

According to Arndt (2003), the ability of trade-oriented Singaporean economy to compete in global market depends on how well it is able to source from lowest cost suppliers, which could have productivity and efficiency gains to the country. In the light of these findings, Thangavelu et al. (2008) studied and suggested a strong positive impact of cross border outsourcing on the productivity of the manufacturing sector.

As the future trends of outsourcing is expected to increase in size and manufacturing is identified as one of the higher performing segments by Auguste et al. (2002), more concern emerged. Houseman (2007) suggested that the benefits of outsourcing are more optimistic to low-wage countries. The joint conclusion of Hoon and Ho (2001) and Thangavelu et al. (2008) that production fragmentation is expected to have a widening impact on the wage gap between skilled and unskilled workers as the well-planned Singaporean economy restructures towards a knowledge intensive economy has not been thoroughly investigated. Table 1 summarizes key empirical studies, their limitations and contribution of present study.

Table 1. Key studies addressing regime switching on outsourcing measurement and its impact on wages

\begin{tabular}{|c|c|c|c|c|c|c|}
\hline Past Studies & $\begin{array}{c}\text { Outsourcing } \\
\text { Measurement }\end{array}$ & $\begin{array}{c}\text { Outsourcing } \\
\text { types }\end{array}$ & Impact on Wage & Skill Differentiation & $\begin{array}{c}\text { Regime } \\
\text { Classification on } \\
\text { the basis of } \\
\text { outsourcing } \\
\text { intensity }\end{array}$ & $\begin{array}{l}\text { Doesthe estimation } \\
\text { method address } \\
\text { Regime Switching? }\end{array}$ \\
\hline $\begin{array}{l}\text { Feenstra and } \\
\text { Hanson } \\
(1996,1999)\end{array}$ & $\begin{array}{c}\text { Using Combined } \\
\text { Metrices of } \\
\text { Intermediate Import } \\
\text { in Combination with } \\
\text { Total Import }\end{array}$ & $\begin{array}{c}\text { Narrow and } \\
\text { Wide }\end{array}$ & Analyzed & Not differentiated & Not Analyzed & $\begin{array}{c}\text { Two stage OLS } \\
\text { wage regression } \\
\text { without regime } \\
\text { switch }\end{array}$ \\
\hline
\end{tabular}




\begin{tabular}{|c|c|c|c|c|c|c|}
\hline $\begin{array}{l}\text { Anderton and } \\
\text { Brenton } \\
\text { (1999) }\end{array}$ & $\begin{array}{l}\text { Total Import } \\
\text { penetration }\end{array}$ & $\begin{array}{c}\text { Not } \\
\text { differentiated }\end{array}$ & Analyzed & $\begin{array}{c}\text { Partially } \\
\text { Differentiated in High } \\
\text { and Low skill }\end{array}$ & Not Analyzed & $\begin{array}{l}\text { Three stage Linear } \\
\text { OLS panel } \\
\text { estimation }\end{array}$ \\
\hline $\begin{array}{l}\text { Hijzen } \\
\text { (2007); } \\
\text { Hijzen, A et } \\
\text { al. (2005) }\end{array}$ & $\begin{array}{c}\text { Same as Feenstra } \\
\text { and Hanson }\end{array}$ & $\begin{array}{l}\text { Narrow and } \\
\text { Wide }\end{array}$ & $\begin{array}{l}\text { Analyzed assuming } \\
\text { constant returns to } \\
\text { scale (linear and } \\
\text { homogenous } \\
\text { production process) }\end{array}$ & $\begin{array}{l}\text { International } \\
\text { Standard } \\
\text { Occupational } \\
\text { Classification }\end{array}$ & Not analyzed & $\begin{array}{l}\text { Same as Feenstra } \\
\text { and Hansen with } \\
\text { additional variables } \\
\text { for Sector and Factor } \\
\text { bias }\end{array}$ \\
\hline $\begin{array}{l}\text { Hoon and Ho } \\
\text { (2001) }\end{array}$ & Theoretical work & - & - & - & - & - \\
\hline $\begin{array}{c}\text { Egger and } \\
\text { Stehrer (2003) }\end{array}$ & Final Trade & $\begin{array}{c}\text { Not } \\
\text { differentiated }\end{array}$ & Analyzed & $\begin{array}{l}\text { Assuming Manual } \\
\text { workers as Unskilled } \\
\text { and Non-manual } \\
\text { workers as Skilled } \\
\text { International }\end{array}$ & Not Analyzed & $\begin{array}{c}\text { Panel OLS } \\
\text { regression with time } \\
\text { dummy }\end{array}$ \\
\hline $\begin{array}{c}\text { Geishecker \& } \\
\text { Görg (2008) }\end{array}$ & $\begin{array}{c}\text { Same as Feenstra } \\
\text { and Hanson }\end{array}$ & $\begin{array}{l}\text { Narrow and } \\
\text { Wide }\end{array}$ & Analyzed & $\begin{array}{c}\text { Standard } \\
\text { Occupational } \\
\text { Classification }\end{array}$ & Not Analyzed & $\begin{array}{c}\text { Static OLS Panel } \\
\text { model with dummies }\end{array}$ \\
\hline $\begin{array}{c}\text { Thangavelu, } \\
\text { Toh and Ng } \\
\text { (2008) }\end{array}$ & $\begin{array}{c}\text { Same as Feenstra } \\
\text { and Hanson }\end{array}$ & Only Narrow & $\begin{array}{l}\text { Not Analyzed } \\
\text { (Impact of labour } \\
\text { productivity is } \\
\text { analyzed) }\end{array}$ & Not Considered & Not Analyzed & $\begin{array}{c}\text { Static OLS Panel } \\
\text { model with dummies }\end{array}$ \\
\hline This study & $\begin{array}{c}\text { Same as Feenstra } \\
\text { and Hanson }\end{array}$ & $\begin{array}{l}\text { Narrow and } \\
\text { Wide }\end{array}$ & Analyzed & $\begin{array}{l}\text { International } \\
\text { Standard } \\
\text { Occupational } \\
\text { Classification }\end{array}$ & $\begin{array}{l}\text { Considered } \\
\text { through Markov } \\
\text { Switching } \\
\text { Dynamic } \\
\text { regression }\end{array}$ & $\begin{array}{c}\text { Address through } \\
\text { Maximum } \\
\text { Likelihood } \\
\text { estimation of } \\
\text { Markov Switching } \\
\text { Auto-Regression }\end{array}$ \\
\hline
\end{tabular}

Hence there lies a scope for future research to understand the relationship of outsourcing in the worker's wage of the domestic country. This paper investigates the impact of international outsourcing on skilled and unskilled worker in manufacturing industry utilizing individual and industry characteristics. As individual firms benefit from the cost-saving they achieved from international outsourcing, government needs to quantify its impact on labor force and economy.

The objective of this paper is to investigate the impact of international outsourcing in the wages of manufacturing workers in Singapore. As the Singapore manufacturing structure developed and business firms relied on external resource for their production supply, effect of outsourcing on wage gap for skilled and unskilled employees becomes a concern on Singapore domestic market that has not been investigated in the economy.

Rest of study work is organized as follow. Section 2 briefly discusses the theoretical base wherein the body of the knowledge in this study is based. Section 3 surveys the primary studies and posteriori investigation on international outsourcing and wages paying attention to the methodology adapted and results. The evaluations end with a discussion of the feasible methodological improvements over these existing empirical accounts of international outsourcing. Section 4 details the research paper design, which includes measurement procedure, data description and frame of analysis. Empirical results of the study are covered in Section 5 and conclusions follow in Section 6.

\section{Theoretical Base}

The connection of international outsourcing and rising inequality of relative wages are based on Heckscher-Ohlin (HO) model and Stolper-Samuelson (SS) theorem. In the HO propositions, the skilled labor abundant nation A will export skill intensive goods to other nation 'B' with scarce resource of skilled labor. This situation will limit the abundant supply of skill intensive goods in nation 'A' which will result in increase in its relative prices. In accordance to SS proposition, the price movement will increase the skilled wage and decrease the unskilled wage in nation 'A'.

Figure 1 show the impact of import on wage and labor. Labor supply $\left(\mathrm{S}_{\mathrm{B}, \mathrm{W}}\right)$ is not affected with the international 
outsourcing, however labor demand (D) contracted as the international outsourcing level increases, labor shifts from point A to B. In response to labor surplus, wages decreases to promote labor demand. The corresponding increase of outsourcing level from $\mathrm{O} 1$ to $\mathrm{O} 2$ resulted to downward shift of wages from point $\mathrm{A}$ to $\mathrm{C}$.

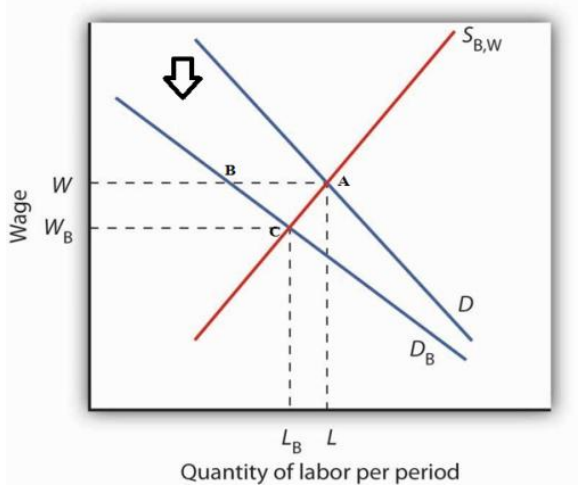

Figure 1. Labor and wage impact

This process of international trade caused the wage gap between skilled and unskilled laborers in domestic market of nation with limited supply of unskilled labor and abundant supply of skilled labor. Lately, the HO model and SS theorems validity in modern context has been questioned. For example, Davis and Mishra (2007) argue that the SS theorem is "history" because following trade liberalization in some developing countries, wage inequality rose. On the other hand, under the assumption that these countries are labor-abundant, the SS theorem predicts that wage inequality should have fallen.

\section{Primary Studies and Posteriori Investigation of Methodology Adopted}

Studies that have been taken in the past between trade and wages differ with respect to dimensionality, structure and calibration. Pioneering studies suggest building of a theoretically consistent equilibrium model that allows introduction of shocks representing changes in trade to test HO models and SS theorem suggesting thereby how future research should proceed.

These pioneering studies were the first to contribute on trade and wage inequality. The surveyed studies, reveal that trade has led to the formation of wage gap of skilled and un-skilled workers by at most 5 percent. Perhaps, this means that trade does not fully explain the formation of wage gap and there exist other factors impacting more to the wage gap as compared to trade. Supporting evidences has been found from Tyers and Yang (1997), Tokarick (2005) and Winchester (2008) that have concluded of declining wage inequality with respect to an increase in quantum of trade.

De Santis (2003) explained the 18 per cent increase in the UK skill premium between 1979 and 1992 by adopting technology shocks. According to De Santis, there are two type of shocks, the first which is termed as trade shock, imply reduction in trade cost which results in an increase in wage inequality as it encourages trading between nations of skill and unskilled abundant resources. The second shock is the fixing of number of foreign capital goods by introducing an endogenous skilled labor boosting technical change in manufacturing which resulted in an increase in wage inequality. This variant on the reduction of trade cost explains the large increase of capital goods imports and contraction of manufacturing in the UK.

Robinson and Theirfelder (2002) studied a fifteen-sector and six factor model calibrated to the 1982 US economy. Two shocks were considered which includes the 50 percent reduction in the world price of imports and a $\$ 200$ billion increase in trade balance. The combined effects of these two shocks resulted in 1.25 percent increase in the professional to low skill relative wage. Thus, the authors conclude that trade is responsible for very little of the wage gap,

From more than a decade of analysis in the impact of international trade on wages using HO propositions has explained relatively lesser as compared to the role played by other factors though in the short run, when it is difficult for unskilled workers to move out of the manufacturing sectors, trade shocks can have a strong impact on the wage gap (Davis \& Mishra, 2007).

Tyers and Yang (1997) have studied the effect of trade liberalizations and development of rapidly developing economies. The study has covered Old Country Economies (OIE's) namely, North America, the EU, Australasia, Japan and the Rapidly Developing Economies (RDE's) namely, China, Indonesia, Republic of Korea, Hong 
Kong, Malaysia, Singapore, Taiwan and Thailand. Five explanatory factors of production and thirty-two sectors have been considered in the study. The authors have conducted a backward examination of the effects of increased trade openness and dramatic expansion of RDE's between periods of 1970-92. The study has found that trade has increased the wage inequality of skilled-unskilled by 0.2 per cent, 0.3 per cent and 0.9 per cent in North America, Australia, and Asia, respectively, and by about 6 percent in the EU.

Winchester (2008) explored the impact of trade on wages in New Zealand as they imported more from RDEs than either the US or the UK. Conducting the study that includes data for four labor types with different qualifications and controlling for trade shocks, import tariffs and export taxes in other regions between years 1980 to 2001. The author documented that trade shock has reduced the wage inequality in New Zealand for those with degree compared to no qualifications by 3.46 per cent. The same study has concluded that a Country has an advantage to make full use of unskilled labor in large sector of agriculture products.

Despite the strong link between trade and wages in pioneering studies, empirical studies provide support for the consensus in the wider empirical literature as it presents a real world investigation to validate the propositions.

Borjas and Ramey (1994) conducted a time series investigation based on the USA samples to identify the change in wage of non-educated employees. The measure of outsourcing was based on trade of durable goods using Input and Output information. The study found a high correlation between wage inequality and trade in durable goods between years 1964-91.

Supporting evidences have also been found from Rigby and Breau (2008) who have used a matched employer-employee data in Los Angeles to analyze the trade and inequality link. Resorting to a different measure of outsourcing as reflected in components of foreign competition that is composed of trade openness, import competition and trade competition, results from this study has shown that the three measure of outsourcing has significantly reduced the wages of workers with the lowest educational attainment across manufacturing sector.

In Hong Kong, Ho et al. (2004) studied the impact on wage inequality of outward processing trade with Chinese Mainland using a quarterly time-series data and adopting the measure of outsourcing from Feenstra and Hanson (1999). The same study has shown that the outward processing trade has compressed the wage of less skilled workers while raising the wage for more skilled workers.

In Germany, Geishecker and Görg (2008) have studied the change in wage for three skill group using a panel data for years 1991-2000. Their measure of outsourcing adopted the Feenstra and Hanson (1999) measure in terms of imports of overseas intermediate goods, results has shown that international outsourcing has positive effect on high skilled workers by receiving higher wages while a negative effect on low-skilled workers does exist.

In Japan, Yamashita (2007) tested the hypothesis that firms involved in international outsourcing in production undergo skill upgrading due to increased share of non-production workers in total workforce. Their measure of outsourcing focused on imports and exports of intermediate components and parts in production. The hypothesis of the study has been proved since the greater reliance from East Asian countries components and parts has contributed to change in share employment in skilled worker over the period of 1980-2000.

In China, Anwar and Sun (2010) measured the impact of trade liberalization and market competition on the wage inequality of skilled and unskilled worker in China in year 2003, 2006 and 2007. Their empirical investigation has implied that trade liberalization has positive impact while market competition has negative impact on wage inequality of skilled and unskilled workers in China.

\section{Research Design}

\subsection{The Baseline Emperical Literature}

The empirical method followed in this study starts with a structure laid down by Geishecker \& Görg (2008). In their framework, the specification comes in what is given below.

$$
\ln \left(W_{i j, t}\right)=\alpha+\beta D E M O G_{i t}+\gamma W O R K_{i t}+\delta E D U C_{i t}+\theta I N D_{j t}+\lambda O U T_{j t}+\varepsilon_{i t}
$$

Where the dependent variable $\ln \left(W_{i j, t}\right)$ is the hourly wage of worker $\mathrm{i}$ in industry $\mathrm{j}$ at time t.

With additional support from the literature, e.g., (Mincer, 1974; Brown \& Medoff, 1989; and Schmidt \& Zimmerman, 1991), control variables in the standard regression have been adopted. The list of variables under study are respectively named as $D E M O G_{i t}$ representing demographic control variables for gender and age, $W_{O R K_{i t}}$ representing individual characteristics related to the workplace such as firm size and nature of ownership of the firm, $E D U C_{i t}$ representing the skill structure in the manufacturing industry based on educational attainment such as high education (ISCED: high), medium education (ISCED : med); and low 
education (ISCED: low), $I N D_{j t}$ representing the industry characteristics in terms of its size based on output and value of capital structure of plant \& machineries and the explanatory variable $O U T_{j t}$ narrow and a wide based on definition of international outsourcing. The error term $\varepsilon_{i t}$ assumed the model to be normally distributed.

In the context of measurement of international outsourcing, Feenstra and Hanson (1999) measure of international outsourcing has been widely used in academic literature (see Strauss-Kahn, 2003; Ito \& Fukao, 2005; Hijzen et al., 2005; Hsieh \& Woo, 2005), wherever they have used the Input and Output information to measure to measure the degree of international outsourcing. Following the same approach that has been used in the above stated studies, this study considers narrow outsourcing that includes imported intermediate inputs from the same industry abroad while wide outsourcing includes all imported intermediate goods from the other industry abroad as a share of the industry's production total value. Thus narrow and wide outsourcing is given by following expressions:

$O U T_{j t}^{\text {Narrow }}=\frac{I M P_{j t}}{Y_{j t}}$ and $O U T_{j t}^{\text {Wide }}=\sum_{j} \frac{I M P_{j t}}{Y_{j t}}$ Where $j t$ denotes the respective 2-digit manufacturing industry at time $t, I M P$ is value of imported intermediate inputs from foreign industry and $Y$ represent the industry output value.

\subsection{Data and Revised Methodology}

The data is sourced from Singapore Input and Output table (I-O, henceforth) that comprises of Import matrix having records of the imported commodities purchased by industries and types of usage in terms of intermediate goods of final demand. The I-O tables were composed based on 152 industrial sectors and 152 commodities. The industrial classification is based on the 2000 Singapore Industrial Classification (SSIC 2000) and the commodity classification follows the Standard International Trade Classification (SITC).

For the final estimation process this study critically reviews the model of Geishecker and Görg (2008) and finds the same having some limitations and can be further improved upon. First, it does not take into considerations auto correlations and cross correlations among dependent and independent variables. Second, the parameters of estimation does not ascertain stability of consistency should there be any structural changes or regime switching process which may stem from institutional changes. To address the first limitation, the modified model takes into account a lead-lag relationship among the dependent and independent variables thereby allowing the past values of outsourcing amongst other to influence the wage gap. To address the second limitation, the modified model incorporates an element of hidden regime switching factor. Regime switching is phenomena that comes from instuitional changes and has strong influence on a dynamic system of equation. The model of Geishecker and Görg (2008) can work in a situation where there are no structural breaks (regime switches) which is very unlikely to happen in a temporal dependence structure. One of the most popular models in addressing and estimating regime switching effect is the Markov Switching Model. A number of studies have used Markov Switching model to describe the causal structure amongst the variables. For example, see the works of (Jerzmanowski, 2005; Hansen, 1992; Engel, 1993; Simon, 1996; Krolzig et al., 2002; McCulloch \& Tsay, 1994).

In view of the above mentioned literature on Markov Switching framework, the modified model can be represented by:

\section{State/Regime 1}

$$
\ln \left(W_{i j, t}\right)=\alpha_{1}+\beta_{1} D E M O G_{i t}+\gamma_{1} W_{O R K_{i t}}+\delta_{1} E D U C_{i t}+\theta_{1} I N D_{j t}+\lambda_{1} O U T_{j t}+\psi_{1} \ln \left(W_{i j, t-1}\right)+\varepsilon_{i t}\left(\text { when } S_{t}=1\right)
$$

\section{State/Regime 2}

$$
\ln \left(W_{i j t}\right)=\alpha_{2}+\beta_{2} D E M O G_{i t}+\gamma_{2} W_{O R K_{i t}}+\delta_{2} E D U C_{i t}+\theta_{2} I N D_{j t}+\lambda_{2} O U T_{j t}+\psi_{2} \ln \left(W_{i j, t-1}\right)+\varepsilon_{i t}\left(\text { when } S_{t}=2\right)
$$

with the probabilities pertaining to different regimes, given by

$$
\begin{aligned}
& P\left(S_{t}=1 \mid S_{t-1}=1\right)=p_{11} \\
& P\left(S_{t}=2 \mid S_{t-1}=1\right)=p_{12} \\
& P\left(S_{t}=1 \mid S_{t-1}=2\right)=p_{21} \\
& P\left(S_{t}=2 \mid S_{t-1}=2\right)=p_{22}
\end{aligned}
$$

Such that $\sum_{j} p_{i j}=\sum_{i} p_{i j}=1, i, j=1,2$

Or, in the combined form,

$$
\begin{gathered}
\ln \left(W_{i j t}\right)=\alpha_{k, S_{t}}+\beta_{k, S_{t}} D E M O G_{i t}+\gamma_{k, S_{t}} W_{\text {ORK }}+\delta_{k, S_{t}} E D U C_{i t}+\theta_{k, S_{t}} I N D_{j t}+\lambda_{k, S_{t}} O U T_{j t}+\psi_{k, S_{t}} \ln \left(W_{i j, t-1}\right)+\varepsilon_{t}, \\
\text { where } \varepsilon_{t} \sim N I I D\left(0, \sigma^{2} \mid \Omega_{t-1}\right)
\end{gathered}
$$


Under the assumption of normality, the conditional density function of $\ln \left(W_{i j t}\right)$ is given by

$$
\begin{aligned}
& f\left[\ln \left(W_{i j t}\right) \mid S_{t}=j, \Omega_{t-1} ; \tau\right]=\frac{1}{\sqrt{2 \pi \sigma}} \exp \left[\frac{-\left\{\ln \left(W_{i j t}\right)-\phi_{j}^{\prime} \Delta_{t}\right\}^{2}}{2 \sigma^{2}}\right] \\
& \text { where, } \quad \Delta_{t}=\left[1, D E M O G_{i t}, W_{\text {ORK }}, E D U C_{i t}, I N D_{j t}, O U T_{j t}, \ln \left(W_{i j, t-1}\right)\right]^{\prime}, \phi_{j}=\left(\alpha_{k, S_{t}}, \beta_{k, S_{t}}, \gamma_{k, S_{t}}, \delta_{k, S_{t}}, \theta_{k, S_{t}}, \lambda_{k, S_{t}},\right. \\
& \left.\psi_{k, S_{t}}\right), \tau=\left(\phi_{1}^{\prime}, \phi_{2}^{\prime}, p_{11}, p_{22}, \sigma^{2}\right)^{\prime}
\end{aligned}
$$

The log-transformed density can be represented by

$$
\operatorname{Ln}[f(.)]=\sum_{j=1}^{2} f\left[\ln \left(W_{i j t}\right) \mid S_{t}=j, \Omega_{t-1} ; \tau\right] . P\left(S_{t}=j \mid \Omega_{t-1} ; \tau\right)
$$

The maximum likelihood estimation is done with the conditions that

And

$$
\frac{\partial\{\operatorname{Ln}[f(.)]\}}{\partial\left(\alpha_{k, S_{t}}, \beta_{k, S_{t}}, \gamma_{k, S_{t}}, \delta_{k, S_{t^{\prime}}}, \theta_{k, S_{t^{\prime}}} \lambda_{k, S_{t^{\prime}}}, \psi_{k, S_{t}}\right)}=0
$$

$$
\frac{\partial\{\operatorname{Ln}[f(.)]\}}{\partial\left(\phi_{1}^{\prime}, \phi_{2}^{\prime}, p_{11}, p_{22}, \sigma^{2}\right)}=0
$$

The estimated probabilities are given by

$$
\widehat{p_{l \jmath}}=\frac{\sum_{t=2}^{n} P\left(S_{t}=j, S_{t-1}=i \mid \Omega_{n} ; \hat{\tau}\right)}{\sum_{t=2}^{n} P\left(S_{t-1}=i \mid \Omega_{n} ; \hat{\tau}\right)}
$$

One regime is expected to be the regime of low level of outsourcing probability and the other is expected to be the high level.

Ideally, this paper would have liked to explore the potential usefulness of this model before actually attempting to estimate it. However, according to Zivot and Wang (2006) no such test for Markov Switching Model is available. Only after estimating in a 2-regime model can one assess the relevance of the additional regime. To address the question whether additional regime adds significantly to explaining the dynamic behavior of the time series, the paper compares the in-sample fit of the regime switching model with nonlinear model. Null hypothesis when Ho: $\theta_{1}=\theta_{2}$ which is tested against the alternative hypothesis H1: $\theta_{1} \neq \theta_{2}$.

The statistical test which either take one of the three regime switching models as alternative all suffer from the problem of unidentified nuisance parameter under Null Hypothesis. For this reason, BDS test is more appropriate to use since it is nuisance parameter free and requires no adjustment when applied to fitted model residuals. Brock et al. (1996) proposed BDS test can be used to detect dependence and the presence of a nonlinear structure. This test examines whether the given data is deterministic or stochastic based on a calculation of the Correlation integral (Note 1) as given by

If the test value, $F=\frac{C_{2}^{m}(r)-\left[C_{2}^{1}(r)\right]^{m}}{\sigma m}$

with a known distribution function is significantly different from a standard normal distribution, by performing a Gauss test - Test for non-normal-distributed data (Note 2), it can be concluded that the given signal is deterministic.

BDS tests that the proposed model adequately captures all nonlinear features of the time series under investigation. BDS examine the remaining non-linearity to an estimated model. Our BDS test results suggest that the model is adequate in the sense the p-value are such that neither null hypothesis needs to be rejected. Thus, the original nonlinear model cannot be rejected.

The basic framework is adopted from International Standard Classification of Occupations. The Singapore Standard Occupational Classification basically categorized occupations based on the type of work performed. In its basic concept, skill is adopted in defining the type of work. Skills refer to the ability to carry out the tasks and duties of an occupation and have the dimension of skill level and skill specialization. Skill level is based on the complexity and range of the tasks and duties involved while skill specialization is based on the field of knowledge required, tools and machinery, the materials worked on and as well as the kind of goods and services produced (Note 3).

Singapore skill levels are based on International Standard Classification of Education (ISCED). Low skill is for occupations requiring primary or no education, secondary or post-secondary education - Production blue collar workers such as assemblers, operators and manual workers. Medium skill is for occupations requiring tertiary education leading to an award that is not equivalent to a first university degree $=$ Non-production white collar 
workers such as engineers, programmers, buyer, and planner. High skill is for occupations requiring tertiary education leading to a university or postgraduate university degree or the equivalent - thus, more skilled workers are managers, advertising and sales, and accountants. Further, informal training and experiences may be the source to acquire additional skill aside from formal education.

Our study employs individual and industry specific characteristics from 19 manufacturing sectors for the years 1990, 2000, 2005 and 2007 (Note 4). The data was taken from Ministry of Manpower covering individual characteristics information such as number of employees on each gender and age group. The respondents included in the Ministry of Manpower survey were male and female, aged 15-70 years old who were full-time employed more than 6 months in the organization.

Share of employee on each skill classification were obtained through survey conducted by Singapore Statistics Office covering both female and male who are stated to be economically active employee, following the International Standard Classification of Occupations.

The data from industry specific characteristics such as wages, capital structure, firm size and capital expenditures were sourced from Singapore Economic Development Board website. Wages refers to the average gross hourly income which includes bonuses, contribution to central provident fund and the value of other benefits provided by employer. Capital structure refers to the number of employee under each type of firm ownership if wholly locally, more than half local or foreign and wholly foreign. Capital expenditures cover all expenditures on capital assets namely plant and machinery or equipment.

\section{Results}

Using a non-linear Markov-switching model allows us to analyze the dynamics of the switching to high and low level of outsourcing probability in Singapore. The estimation results are interpreted, within the theoretical framework taking regime shifts as jumps between different levels of outsourcing probabilities. According to the theoretical model, these jumps are generated by shifts in internal factors such as business objective and confidence on outsourcing suppliers; and external factors such as international trade agreements and policies. Thus, regime shifts are generated by shift in manufacturing business objectives and international trade policies. To prove whether shift in levels of outsourcing probability has an impact of wage level for skilled and unskilled workers, the paper estimates a Markov-switching model with two regimes. One regime is expected to be the regime of low level of outsourcing probability and the other is expected to be the high level.

Table 2. Wage regression of outsourcing

\begin{tabular}{|c|c|c|c|c|c|c|c|c|}
\hline \multicolumn{3}{|c|}{ Overall Outsourcing - MSAR } & \multicolumn{3}{|c|}{ Narrow Outsourcing-MSAR } & \multicolumn{3}{|c|}{ Wide Outsourcing -- MSAR } \\
\hline Parameter & Coefficient & t-prob & Parameter & Coefficient & t-prob & Parameter & Coefficient & t-prob \\
\hline Constant $(0)$ & 64.3969 & 0.0000 & Constant $(0)$ & 68.5631 & 0.0000 & Constant(0) & 67.9158 & 0.0000 \\
\hline Constant(1) & 9.8337 & 0.0000 & Constant(1) & 1.8689 & 0.0000 & Constant(1) & 61.9374 & 0.0000 \\
\hline $\mathrm{NO}(0)$ & 0.0180 & 0.0130 & $\mathrm{NO}(0)$ & 0.0175 & 0.0130 & $\mathrm{~A} 1(0)$ & 0.0001 & 0.9820 \\
\hline $\mathrm{NO}(1)$ & -0.0088 & 0.5830 & $\mathrm{NO}(1)$ & 0.0074 & 0.5160 & $\mathrm{~A} 1(1)$ & 0.0000 & 1.0000 \\
\hline $\mathrm{WO}(0)$ & 0.0080 & 0.0000 & $\mathrm{~A} 1(0)$ & 0.0001 & 0.5340 & $\mathrm{~A} 2(0)$ & 0.0000 & 0.9970 \\
\hline WO(1) & 0.0001 & 0.9830 & A1(1) & -0.0006 & 0.9800 & $\mathrm{~A} 2(1)$ & -0.0010 & 0.9980 \\
\hline $\mathrm{A} 1(0)$ & 0.0000 & 0.9210 & $\mathrm{~A} 2(0)$ & 0.0000 & 0.8850 & $\mathrm{~A} 3(0)$ & 0.0000 & 0.9990 \\
\hline $\mathrm{A} 1(1)$ & -0.0003 & 0.9550 & $\mathrm{~A} 2(1)$ & 0.0000 & 0.9990 & A3(1) & -0.0009 & 0.9990 \\
\hline $\mathrm{A} 2(0)$ & 0.0000 & 0.9640 & $\mathrm{~A} 3(0)$ & 0.0000 & 0.9170 & $\mathrm{~A} 4(0)$ & 0.0007 & 0.8120 \\
\hline $\mathrm{A} 2(1)$ & -0.0001 & 0.9900 & A3(1) & 0.0001 & 0.9950 & $\mathrm{~A} 4(1)$ & 0.0028 & 0.9850 \\
\hline $\mathrm{A} 3(0)$ & 0.0000 & 0.9050 & $\mathrm{~A} 4(0)$ & 0.0004 & 0.0110 & $\mathrm{~A} 5(0)$ & 0.0000 & 0.9990 \\
\hline A3(1) & -0.0001 & 0.9920 & $\mathrm{~A} 4(1)$ & 0.0004 & 0.9940 & $\mathrm{~A} 5(1)$ & 0.0003 & 0.9990 \\
\hline $\mathrm{A} 4(0)$ & 0.0006 & 0.0040 & $\mathrm{~A} 5(0)$ & 0.0001 & 0.5110 & $\mathrm{~A} 6(0)$ & 0.0000 & 0.9970 \\
\hline $\mathrm{A} 4(1)$ & 0.0008 & 0.9730 & $\mathrm{~A} 5(1)$ & -0.0007 & 0.9870 & A6(1) & 0.0012 & 0.9940 \\
\hline $\mathrm{A} 5(0)$ & -0.0001 & 0.4860 & $\mathrm{~A} 6(0)$ & 0.0000 & 0.9820 & $\mathrm{~A} 7(0)$ & -0.0001 & 0.9820 \\
\hline $\mathrm{A} 5(1)$ & -0.0002 & 0.9920 & A6(1) & -0.0002 & 0.9970 & A7(1) & 0.0003 & 0.9980 \\
\hline $\mathrm{A} 6(0)$ & 0.0000 & 0.8690 & $\mathrm{~A} 7(0)$ & 0.0000 & 0.8380 & $\mathrm{~A} 8(0)$ & 0.0000 & 0.9950 \\
\hline $\mathrm{A} 6(1)$ & 0.0001 & 0.9960 & A7(1) & 0.0001 & 0.9990 & $\mathrm{~A} 8(1)$ & -0.0002 & 0.9990 \\
\hline $\mathrm{A} 7(0)$ & 0.0000 & 0.9190 & $\mathrm{~A} 8(0)$ & 0.0000 & 0.9980 & $\mathrm{~A} 9(0)$ & 0.0000 & 0.9990 \\
\hline A7(1) & 0.0001 & 0.9950 & A8(1) & 0.0003 & 0.9970 & A9(1) & -0.0004 & 0.9990 \\
\hline $\mathrm{A} 8(0)$ & 0.0001 & 0.9670 & A9(0) & -0.0001 & 0.9540 & $\mathrm{~A} 10(0)$ & -0.0001 & 0.9990 \\
\hline A8(1) & 0.0000 & 1.0000 & A9(1) & 0.0007 & 0.9960 & A10(1) & -0.0003 & 0.9990 \\
\hline
\end{tabular}




\begin{tabular}{|c|c|c|c|c|c|c|c|c|}
\hline $\mathrm{A} 9(0)$ & 0.0001 & 0.9710 & $\mathrm{~A} 10(0)$ & -0.0001 & 0.9750 & $\mathrm{~A} 11(0)$ & 0.0000 & 1.0000 \\
\hline A9(1) & 0.0002 & 0.9990 & $\mathrm{~A} 10(1)$ & 0.0006 & 0.9970 & A11(1) & -0.0002 & 1.0000 \\
\hline $\mathrm{A} 10(0)$ & 0.0001 & 0.9780 & A11(0) & 0.0000 & 0.9860 & $\mathrm{~A} 12(0)$ & 0.0000 & 1.0000 \\
\hline $\mathrm{A} 10(1)$ & 0.0002 & 0.9990 & A11(1) & 0.0003 & 0.9970 & $\mathrm{~A} 12(1)$ & -0.0001 & 1.0000 \\
\hline A11(0) & 0.0000 & 0.9910 & A12(0) & 0.0000 & 0.9960 & $\mathrm{G} 1(0)$ & -0.0003 & 0.0000 \\
\hline A11(1) & 0.0001 & 1.0000 & A12(1) & 0.0001 & 0.9990 & G1(1) & -0.0005 & 0.1570 \\
\hline $\mathrm{A} 12(0)$ & 0.0000 & 0.9980 & $\mathrm{G} 1(0)$ & -0.0004 & 0.0000 & $\mathrm{G} 2(0)$ & 0.0009 & 0.5780 \\
\hline A12(1) & 0.0000 & 1.0000 & G1(1) & 0.0007 & 0.2600 & G2(1) & 0.0013 & 0.8880 \\
\hline $\mathrm{G} 1(0)$ & -0.0002 & 0.0000 & $\mathrm{G} 2(0)$ & 0.0007 & 0.0060 & $\mathrm{FS} 1(0)$ & 0.0000 & 0.9980 \\
\hline G1(1) & 0.0005 & 0.2200 & G2(1) & -0.0002 & 0.9860 & FS1(1) & 0.0005 & 0.9980 \\
\hline G2(0) & 0.0012 & 0.0000 & FS1(0) & 0.0000 & 0.8060 & FS2(0) & 0.0000 & 0.9990 \\
\hline G2(1) & -0.0001 & 0.9900 & FS1(1) & -0.0002 & 0.9970 & $\mathrm{FS} 2(1)$ & 0.0000 & 1.0000 \\
\hline $\mathrm{FS} 1(0)$ & 0.0000 & 0.8910 & $\mathrm{FS} 2(0)$ & 0.0000 & 0.7750 & FS3(0) & 0.0000 & 0.9960 \\
\hline FS1(1) & 0.0000 & 1.0000 & FS2(1) & -0.0001 & 0.9990 & FS3(1) & -0.0003 & 0.9810 \\
\hline $\mathrm{FS} 2(0)$ & 0.0000 & 0.9080 & $\mathrm{FS} 3(0)$ & 0.0000 & 0.9550 & FS4(0) & 0.0000 & 0.9970 \\
\hline $\mathrm{FS} 2(1)$ & 0.0000 & 0.9990 & $\mathrm{FS} 3(1)$ & 0.0001 & 0.9960 & FS4(1) & 0.0000 & 0.9970 \\
\hline $\mathrm{FS} 3(0)$ & 0.0000 & 0.8960 & FS4(0) & 0.0000 & 0.9410 & $\mathrm{CS} 1(0)$ & -0.0006 & 0.0000 \\
\hline FS3(1) & 0.0000 & 0.9990 & FS4(1) & 0.0002 & 0.9900 & CS1(1) & -0.0010 & 0.5870 \\
\hline $\mathrm{FS} 4(0)$ & 0.0000 & 0.9290 & $\operatorname{CS} 1(0)$ & -0.0003 & 0.0100 & $\mathrm{CS} 2(0)$ & 0.0000 & 0.9990 \\
\hline FS4(1) & 0.0001 & 0.9920 & CS1(1) & -0.0003 & 0.9150 & $\operatorname{CS} 2(1)$ & -0.0002 & 1.0000 \\
\hline $\mathrm{CS} 1(0)$ & -0.0010 & 0.0000 & $\mathrm{CS} 2(0)$ & 0.0001 & 0.5050 & $\mathrm{CS} 3(0)$ & 0.0000 & 0.9550 \\
\hline CS1(1) & -0.0006 & 0.6940 & $\mathrm{CS} 2(1)$ & -0.0005 & 0.9830 & $\mathrm{CS} 3(1)$ & 0.0003 & 0.9450 \\
\hline $\mathrm{CS} 2(0)$ & -0.0001 & 0.6310 & $\mathrm{CS} 3(0)$ & 0.0000 & 0.7630 & $\mathrm{P}(0)$ & 0.1548 & 0.0000 \\
\hline $\mathrm{CS} 2(1)$ & -0.0002 & 0.9920 & CS3(1) & -0.0003 & 0.9660 & $\mathrm{P}(1)$ & 0.1015 & 0.0000 \\
\hline $\mathrm{CS} 3(0)$ & 0.0000 & 0.7180 & $\operatorname{LOW}(0)$ & -36.7763 & 0.0000 & $\operatorname{EM}(0)$ & 0.0949 & 0.0000 \\
\hline $\mathrm{CS} 3(1)$ & -0.0001 & 0.9790 & LOW(1) & -2.1273 & 0.0350 & $\operatorname{EM}(1)$ & 0.5608 & 0.0000 \\
\hline $\operatorname{LOW}(0)$ & -35.9820 & 0.0000 & MEDIUM(0) & 50.7904 & 0.0000 & $\mathrm{TO}(0)$ & 2.3886 & 0.0000 \\
\hline LOW(1) & -5.5270 & 0.0000 & MEDIUM(1) & -4.3107 & 0.0000 & $\mathrm{TO}(1)$ & -2.0571 & 0.0130 \\
\hline $\operatorname{MEDIUM}(0)$ & 49.4558 & 0.0000 & $\operatorname{HIGH}(0)$ & -13.5191 & 0.0000 & $\mathrm{WO}(0)$ & 0.0106 & 0.0000 \\
\hline MEDIUM(1) & 0.9742 & 0.0680 & HIGH(1) & 6.6810 & 0.0000 & $\mathrm{WO}(1)$ & -0.0028 & 0.6570 \\
\hline $\operatorname{HIGH}(0)$ & 12.7074 & 0.0000 & $\mathrm{P}(0)$ & 0.1790 & 0.0000 & $\operatorname{LOW}(0)$ & -38.3007 & 0.0000 \\
\hline HIGH(1) & 4.6858 & 0.0070 & $\mathrm{P}(1)$ & 0.0703 & 0.0300 & LOW(1) & -27.9228 & 0.0000 \\
\hline $\mathrm{P}(0)$ & 0.2101 & 0.0000 & $\operatorname{EM}(0)$ & 0.0841 & 0.0000 & MEDIUM(0) & 53.5699 & 0.0000 \\
\hline $\mathrm{P}(1)$ & 0.0881 & 0.0060 & $\operatorname{EM}(1)$ & 0.5561 & 0.0000 & MEDIUM(1) & 37.6403 & 0.0000 \\
\hline $\operatorname{EM}(0)$ & 0.0877 & 0.0000 & $\mathrm{TO}(0)$ & 2.2878 & 0.0000 & $\operatorname{HIGH}(0)$ & -14.2172 & 0.0000 \\
\hline $\operatorname{EM}(1)$ & 0.5501 & 0.0000 & $\mathrm{TO}(1)$ & -1.6733 & 0.0320 & HIGH(1) & -10.6581 & 0.0000 \\
\hline $\mathrm{TO}(0)$ & 2.2491 & 0.0000 & & & & & & \\
\hline $\mathrm{TO}(1)$ & -1.5373 & 0.0630 & & & & & & \\
\hline
\end{tabular}

Our empirical results tabulated in table 2 displaying the regression results show that post-estimation outsourcing has been found to have an impact on wages of manufacturing sector in Singapore during the two regimes. Both narrow and wide outsourcing are found to be impacting wage during regime of high level of outsourcing (state 1) while narrow and wide outsourcing has no impact on wage during regime of low level of outsourcing (state 2).

Estimating the impact on wages based on overall outsourcing level during the regime of high level of outsourcing (state 1), showed that there is an overall significant impact on wages. As shown in table 2, a one per cent increase in the outsourcing level decreases the wage of low skilled worker by 35 per cent and high skilled worker by 12.7 per cent while it increases the wage of medium skilled worker by 49 Per cent. A shift in low level of outsourcing (state 2), showed no significance on the impact of narrow and wide outsourcing on wages. Other industrial characteristics showed a more significant factor on wages during low level of outsourcing (state 2). The same results were observed when we tried to test the existence of narrow outsourcing and wide outsourcing separately.

The negative impact of outsourcing on low skilled worker by $35 \%$ is true based on the Heckscher-Ohlin trade model; Singapore dependence on unskilled intensive commodity from RCD countries reduced the demand for unskilled labor in domestic market which resulted in a negative shift of wage to induce demand. However, another surprising result was shown on the relative reduction of skilled worker wages by 12 percent. In a more 
competitive goods market, the competition forces firms to employ more productive workers, namely the skilled labor that have higher productivity. Since in a competitive labor market workers are paid at the value of their marginal product, the wage of skilled labor will decline as the employment of skilled labor increases, given the law of diminishing marginal product, which results in the decrease of the wage gap.

Concretely, after estimating autoregressive parameter of the dependent variable wage, the results presented in table 3 further show that the previous wage has more significance on the prediction of current wage compared to the outsourcing both at high level and low level of outsourcing intensity.

Table 3. Wage auto regression of outsourcing

\begin{tabular}{|c|c|c|c|c|c|c|c|c|}
\hline \multicolumn{3}{|c|}{ Overall Outsourcing - MSAR } & \multicolumn{3}{|c|}{ Narrow Outsourcing-MSAR } & \multicolumn{3}{|c|}{ Wide Outsourcing -- MSAR } \\
\hline Parameter & Coefficient & t-prob & Parameter & Coefficient & t-prob & Parameter & Coefficient & t-prob \\
\hline Constant $(0)$ & 55.0089 & 0.0000 & Constant $(0)$ & 52.8759 & 0.0000 & Constant $(0)$ & 61.0525 & 0.0000 \\
\hline Constant(1) & 114.6010 & 0.0000 & Constant(1) & 135.0240 & 0.0000 & Constant(1) & 168.7740 & 0.0000 \\
\hline $\mathrm{NO}(0)$ & 0.0195 & 0.0100 & $\mathrm{NO}(0)$ & 0.0126 & 0.0390 & $\mathrm{~A} 1(0)$ & 0.0001 & 1.0000 \\
\hline $\mathrm{NO}(1)$ & -0.0596 & 0.0000 & $\mathrm{NO}(1)$ & -0.0512 & 0.0000 & $\mathrm{~A} 1(1)$ & 0.0001 & 0.0000 \\
\hline $\mathrm{WO}(0)$ & 0.0043 & 0.0180 & $\mathrm{~A} 1(0)$ & 0.0001 & 1.0000 & $\mathrm{~A} 2(0)$ & 0.0000 & 1.0000 \\
\hline $\mathrm{WO}(1)$ & 0.0064 & 0.0030 & $\mathrm{~A} 1(1)$ & -0.0011 & 0.0000 & $\mathrm{~A} 2(1)$ & -0.0010 & 0.0000 \\
\hline $\mathrm{A} 1(0)$ & 0.0001 & 1.0000 & $\mathrm{~A} 2(0)$ & 0.0000 & 1.0000 & $\mathrm{~A} 3(0)$ & 0.0000 & 1.0000 \\
\hline $\mathrm{A} 1(1)$ & 0.0000 & 0.9990 & $\mathrm{~A} 2(1)$ & -0.0011 & 0.0000 & $\mathrm{~A} 3(1)$ & -0.0011 & 0.0000 \\
\hline $\mathrm{A} 2(0)$ & 0.0000 & 1.0000 & $\mathrm{~A} 3(0)$ & 0.0000 & 1.0000 & $\mathrm{~A} 4(0)$ & 0.0003 & 0.9990 \\
\hline $\mathrm{A} 2(1)$ & -0.0008 & 0.9890 & $\mathrm{~A} 3(1)$ & -0.0012 & 0.0000 & $\mathrm{~A} 4(1)$ & 0.0029 & 0.0000 \\
\hline $\mathrm{A} 3(0)$ & 0.0000 & 1.0000 & $\mathrm{~A} 4(0)$ & 0.0002 & 0.9980 & $\mathrm{~A} 5(0)$ & 0.0001 & 1.0000 \\
\hline $\mathrm{A} 3(1)$ & -0.0009 & 0.9510 & $\mathrm{~A} 4(1)$ & 0.0022 & 0.0000 & $\mathrm{~A} 5(1)$ & 0.0017 & 0.0000 \\
\hline $\mathrm{A} 4(0)$ & 0.0003 & 0.9990 & $\mathrm{~A} 5(0)$ & 0.0001 & 1.0000 & $\mathrm{~A} 6(0)$ & 0.0000 & 1.0000 \\
\hline $\mathrm{A} 4(1)$ & 0.0029 & 0.9690 & $\mathrm{~A} 5(1)$ & 0.0014 & 0.0000 & A6(1) & 0.0018 & 0.0000 \\
\hline $\mathrm{A} 5(0)$ & 0.0001 & 1.0000 & $\mathrm{~A} 6(0)$ & 0.0000 & 1.0000 & $\mathrm{~A} 7(0)$ & 0.0000 & 1.0000 \\
\hline $\mathrm{A} 5(1)$ & 0.0015 & 0.9880 & $\mathrm{~A} 6(1)$ & 0.0019 & 0.0000 & $\mathrm{~A} 7(1)$ & 0.0009 & 0.0000 \\
\hline $\mathrm{A} 6(0)$ & 0.0000 & 1.0000 & $\mathrm{~A} 7(0)$ & 0.0000 & 1.0000 & $\mathrm{~A} 8(0)$ & 0.0000 & 1.0000 \\
\hline $\mathrm{A} 6(1)$ & 0.0015 & 0.9840 & $\mathrm{~A} 7(1)$ & 0.0016 & 0.0000 & $\mathrm{~A} 8(1)$ & -0.0011 & 0.0000 \\
\hline $\mathrm{A} 7(0)$ & 0.0000 & 1.0000 & $\mathrm{~A} 8(0)$ & 0.0000 & 1.0000 & $\mathrm{~A} 9(0)$ & -0.0001 & 1.0000 \\
\hline $\mathrm{A} 7(1)$ & 0.0009 & 0.9570 & $\mathrm{~A} 8(1)$ & -0.0014 & 0.0000 & A9(1) & -0.0014 & 0.0000 \\
\hline $\mathrm{A} 8(0)$ & 0.0000 & 1.0000 & $\mathrm{~A} 9(0)$ & -0.0001 & 0.9990 & $\mathrm{~A} 10(0)$ & -0.0001 & 1.0000 \\
\hline $\mathrm{A} 8(1)$ & -0.0011 & 0.9860 & A9(1) & -0.0009 & 0.0000 & $\mathrm{~A} 10(1)$ & -0.0011 & 0.0000 \\
\hline $\mathrm{A} 9(0)$ & -0.0001 & 1.0000 & $\mathrm{~A} 10(0)$ & -0.0001 & 0.9990 & $\mathrm{~A} 11(0)$ & 0.0000 & 1.0000 \\
\hline A9(1) & -0.0012 & 0.9950 & $\mathrm{~A} 10(1)$ & -0.0005 & 0.0000 & A11(1) & -0.0006 & 0.0000 \\
\hline $\mathrm{A} 10(0)$ & -0.0001 & 1.0000 & $\mathrm{~A} 11(0)$ & 0.0000 & 1.0000 & $\mathrm{~A} 12(0)$ & 0.0000 & 1.0000 \\
\hline $\mathrm{A} 10(1)$ & -0.0009 & 0.9950 & A11(1) & -0.0003 & 0.0000 & $\mathrm{~A} 12(1)$ & -0.0002 & 0.0120 \\
\hline $\mathrm{A} 11(0)$ & 0.0000 & 1.0000 & A12(0) & 0.0000 & 1.0000 & G1(0) & -0.0002 & 0.9130 \\
\hline A11(1) & -0.0005 & 0.9910 & A12(1) & -0.0001 & 0.0080 & G1(1) & -0.0010 & 0.0000 \\
\hline $\mathrm{A} 12(0)$ & 0.0000 & 1.0000 & $\mathrm{G} 1(0)$ & -0.0002 & 0.9830 & $\mathrm{G} 2(0)$ & 0.0004 & 0.9960 \\
\hline $\mathrm{A} 12(1)$ & -0.0002 & 0.9930 & G1(1) & -0.0002 & 0.0000 & $\mathrm{G} 2(1)$ & 0.0042 & 0.0000 \\
\hline $\mathrm{G} 1(0)$ & -0.0002 & 0.4870 & G2(0) & 0.0002 & 0.9990 & $\mathrm{FS} 1(0)$ & 0.0000 & 1.0000 \\
\hline G1(1) & -0.0007 & 0.0000 & G2(1) & 0.0031 & 0.0000 & FS1(1) & 0.0009 & 0.0000 \\
\hline G2(0) & 0.0005 & 0.9500 & $\mathrm{FS} 1(0)$ & 0.0000 & 1.0000 & $\mathrm{FS} 2(0)$ & 0.0000 & 1.0000 \\
\hline G2(1) & 0.0030 & 0.0000 & FS1(1) & 0.0006 & 0.0000 & FS2(1) & 0.0003 & 0.0000 \\
\hline $\mathrm{FS} 1(0)$ & 0.0000 & 1.0000 & $\mathrm{FS} 2(0)$ & 0.0000 & 1.0000 & $\mathrm{FS} 3(0)$ & 0.0000 & 1.0000 \\
\hline FS1(1) & 0.0007 & 0.7490 & $\mathrm{FS} 2(1)$ & 0.0002 & 0.0000 & FS3(1) & -0.0003 & 0.0000 \\
\hline $\mathrm{FS} 2(0)$ & 0.0000 & 1.0000 & FS3(0) & 0.0000 & 1.0000 & FS4(0) & 0.0000 & 1.0000 \\
\hline FS2(1) & 0.0003 & 0.8080 & FS3(1) & -0.0003 & 0.0000 & FS4(1) & -0.0003 & 0.0000 \\
\hline $\mathrm{FS} 3(0)$ & 0.0000 & 0.9980 & FS4(0) & 0.0000 & 1.0000 & $\mathrm{CS} 1(0)$ & -0.0003 & 0.9660 \\
\hline FS3(1) & -0.0003 & 0.0420 & $\mathrm{FS} 4(1)$ & -0.0003 & 0.0000 & $\operatorname{CS} 1(1)$ & -0.0030 & 0.0000 \\
\hline FS4(0) & 0.0000 & 0.9980 & $\operatorname{CS} 1(0)$ & 0.0000 & 0.9990 & $\mathrm{CS} 2(0)$ & 0.0001 & 1.0000 \\
\hline FS4(1) & -0.0003 & 0.3360 & CS1(1) & -0.0028 & 0.0000 & CS2(1) & 0.0008 & 0.0000 \\
\hline $\operatorname{CS} 1(0)$ & -0.0003 & 0.3840 & $\mathrm{CS} 2(0)$ & 0.0001 & 0.9990 & $\mathrm{CS} 3(0)$ & 0.0000 & 0.9990 \\
\hline CS1(1) & -0.0025 & 0.0000 & $\mathrm{CS} 2(1)$ & 0.0005 & 0.0000 & CS3(1) & 0.0008 & 0.0000 \\
\hline
\end{tabular}




\begin{tabular}{ccccccccc}
\hline CS2(0) & 0.0001 & 1.0000 & CS3(0) & 0.0000 & 1.0000 & P(0) & 0.1299 & 0.0070 \\
CS2(1) & 0.0007 & 0.9950 & CS3(1) & 0.0005 & 0.0000 & P(1) & 0.1405 & 0.0000 \\
CS3(0) & 0.0000 & 0.9830 & LOW(0) & -30.2948 & 0.0000 & EM(0) & 0.0526 & 0.0010 \\
CS3(1) & 0.0007 & 0.0000 & LOW(1) & -47.4825 & 0.0000 & EM(1) & 0.2932 & 0.0000 \\
LOW(0) & -33.1452 & 0.0000 & MEDIUM(0) & 39.8323 & 0.0000 & TO(0) & 1.6657 & 0.0000 \\
LOW(1) & -41.3915 & 0.0000 & MEDIUM(1) & 62.4896 & 0.0000 & TO(1) & -1.5371 & 0.0000 \\
MEDIUM(0) & 43.6310 & 0.0000 & HIGH(0) & -8.9685 & 0.0000 & WO(0) & 0.0060 & 0.0010 \\
MEDIUM(1) & 53.2199 & 0.0000 & HIGH(1) & -21.9780 & 0.0000 & WO(1) & -0.0100 & 0.0000 \\
HIGH(0) & -9.6204 & 0.0000 & P(0) & 0.1573 & 0.0040 & LOW(0) & -34.0642 & 0.0000 \\
HIGH(1) & -17.5447 & 0.0000 & P(1) & 0.1112 & 0.0000 & LOW(1) & -60.2390 & 0.0000 \\
P(0) & 0.1879 & 0.0000 & EM(0) & 0.0387 & 0.0050 & MEDIUM(0) & 45.6853 & 0.0000 \\
P(1) & 0.0900 & 0.0000 & EM(1) & 0.2884 & 0.0000 & MEDIUM(1) & 79.1927 & 0.0000 \\
EM(0) & 0.0470 & 0.0010 & TO(0) & 1.4663 & 0.0000 & HIGH(0) & -11.1203 & 0.0000 \\
EM(1) & 0.2918 & 0.0000 & TO(1) & -0.4587 & 0.0000 & HIGH(1) & -27.8992 & 0.0000 \\
TO(0) & 1.5537 & 0.0000 & & & & & & \\
TO(1) & 0.1787 & 0.4550 & & & & & & 0.0000 \\
WAGE_-1(0) & 0.2394 & 0.0000 & WAGE_-1(0) & 0.2834 & 0.0000 & WAGE_-1(0) & 0.2410 & 0.0000 \\
WAGE_-1(1) & 0.2604 & 0.0000 & WAGE_-1(1) & 0.3250 & 0.0000 & WAGE_-1(1) & 0.3767 & 0.0000 \\
\hline
\end{tabular}

Extraneous individual characteristics impact on wage showed that age and gender do not have any significant impact on the domestic wage in manufacturing industry both for two states. This suggests that Singapore work environment has no biasness among its labor force regardless of age and gender. Current labor standards and policies are in place to maintain a fair compensation system. Industry characteristics have a positive impact on wage on all skill level. Regression analysis revealed that the output per employee, capital structure and firm size are significant factors on domestic wage in manufacturing industry for both the states. This showed a positive growth of industry increases wages of employees.

A formal testing procedure of the non-linearity for post Markov estimation was applied using a BDS test, the default values residual error used in the test are converted back to the units of original data, and the null hypothesis that data are independent and identically distributed is rejected at conventional 5 per cent significance level (see Table 4). Since there is no discernible linear structure in the results from the BDS test suggest that there is nonlinearity in the data and the parameters estimated through the Markov Switching Dynamic Regression are stable without any additional nonlinearity.

Table 4. BDS test for independence and identical distribution

\begin{tabular}{ccccc}
\hline \multicolumn{5}{c}{ Test Statistics = } \\
\hline$[2]$ & {$[4.59]$} & {$[9.17]$} & {$[13.76]$} & {$[18.34]$} \\
{$[3]$} & 7.091 & 6.9642 & 7.2382 & 6.6207 \\
{$[4]$} & 7.3585 & 6.8022 & 6.6888 & 5.9175 \\
{$[5]$} & 7.6054 & 6.6478 & 6.0892 & 5.2597 \\
\hline \multicolumn{7}{c}{ p-value } \\
\hline$[2]$ & 8.6228 & 6.6429 & 5.5294 & 4.4768 \\
\hline$[3]$ & {$[4.59]$} & {$[9.17]$} & {$[13.76]$} & {$[18.34]$} \\
{$[4]$} & 0 & 0 & 0 & 0 \\
{$[5]$} & 0 & 0 & 0 & 0 \\
\hline
\end{tabular}

\section{Conclusions}

This paper successfully measured the extent of international outsourcing across manufacturing sector in Singapore by employing panel of industry data on an annual time series for the period of 1990 to 2007 as compared to Glass and Saggi (2001) who used trade data instead in the analysis. The calculation of international outsourcing differs from scope of total imports from a particular source country, as used by Anderton and Brenton (1999) or the method of Feenstra and Hanson (1999) wherein outsourcing was calculated through the use of combined-use matrices in combination with total import penetration ratios calculated from trade data. The direct measure of intermediate goods imported is superior compared to total import penetration, since 
manufacturing fragmentation of production is not driven by increase of trade of final goods but of intermediate goods. The findings of this paper add to the literature of international trade and wage in Singapore context. It provides empirical observation that as individual firms benefit from the cost-saving they achieved from international outsourcing, the labor force wages create an impact across skill levels in Singapore. This result is similar with the previous observation of Geishecker and Gäorg (2008) in Germany. These findings have policy implications for external trade-dependent nations by hinting that the level of international outsourcing impacts the work force skill levels through labor wage rates.

Additionally, this paper extends previous empirical approaches (Glass \& Saggi, 2001; Hijzen et al., 2005; Egger \& Stehrer, 2003; Hijzen, 2007) in the estimation using two models of different regimes of high and low outsourcing probability for three skills data set by allowing switching between regimes so that more complex dynamic patterns can be characterized in time series data.

As have been hypothesized by Hoon and Ho in 2001, the possibility of having a widening wage gap as a result of increasing product fragmentation in Singapore was attempted to answer by this paper. The present findings found that there is a widening impact of wage between skilled and unskilled worker with the existence of narrow and wide outsourcing. Given recent literature (see, Parteka \& Wolszczak-Derlacz, 2015) findings that international outsourcing plays a negligible role in wage equalization, the results have significant policy implications on countries that move through similar economic shifts and progressively increasing socio-economic development. Our findings warn that in the long run this widening gap in wages can impact even the genie index of the economy

The workforce of Singapore in the 21st century moved to a more skill intensive structure resulting to upward shift labor demand domestically and internationally, propelled by increased human capital accumulation as well as technological progress. International outsourcing has impacted on the widening wage gap of all skill level. The dependence on overseas labor intensive intermediate goods and the steady shifts in the industrial and occupational structure of employment toward sectors and job categories that use a greater proportion of more educated workers have contributed to this phenomenon. This leads to another area of concern as the manufacturing industry matures and dependence becomes high on intermediate goods. The impact of displacement of workforce from unskilled to skilled but also displacement from manufacturing industry to other industry has not been examined in the economy. This concern would be of interest to the Singapore Ministry of Manpower and Economic Development Board to ensure that industrial sector will have sufficient and proper placement of workers according to their skill sets. We also expect that the policy implications of our work will impact many other similar economies, especially dependent on their manufacturing sector.

\section{Acknowledgments}

We acknowledge inputs from faculty colleagues especially Prof. Dipankar Mitra in critiquing the manuscript.

\section{References}

Anderton, B., \& Brenton, P. (1999). Outsourcing and Low-skilled Workers in the UK. Bulletin of Economic Research, 51(4), 267-286. https://doi.org/10.1111/1467-8586.00085

Anner, M. (2011). The Impact of International Outsourcing on Unionization and Wages: Evidence from the Apparel Export Sector in Central America. ILR Review, 64(2), 305-322. https://doi.org/10.1177/001979391106400205

Anwar, S., \& Sun, S. (2010). Skilled-Unskilled Wage Gap in China. In Proceedings of the 39th Australian Conference of Economists, pp. 1-24. Economic Society of Australia Inc.

Arbache, J. S., Dickerson, A., \& Green, F. (2004). Trade liberalisation and wages in developing countries. The Economic Journal, 114(493), F73-F96. https://doi.org/10.1111/j.0013-0133.2004.00188.x

Arndt, S. W. (2003). Production sharing and Singapore's global competitiveness. Sustaining Competitiveness in the New Global Economy: the Experience of Singapore (pp. 91-101). Cheltenham: Edward Elgar Publishing.

Auguste, B. G., Hao, Y., Singer, M., \& Wiegand, M. (2002). The other side of outsourcing: Despite the difficulties, there is money to be made running routine operations for other companies. The McKinsey Quarterly, 53-64.

Bengtsson, L., Von Haartman, R., \& Dabhilkar, M. (2009). Low-cost versus innovation: contrasting outsourcing and integration strategies in manufacturing. Creativity and Innovation Management, 18(1), 35-47. https://doi.org/10.1111/j.1467-8691.2009.00510.x 
Bertrand, J. W. M., \& Sridharan, V. (2001). A study of simple rules for subcontracting in make-to-order manufacturing. European Journal of Operational Research, 128(3), 509-531. https://doi.org/10.1016/s0377-2217(99)00371-9

Borjas, G. J., \& Ramey, V. A. (1994). Time-series evidence on the sources of trends in wage inequality. The American Economic Review, 84(2), 10-16.

Chen, L. H., \& Hung, C. C. (2010). An integrated fuzzy approach for the selection of outsourcing manufacturing partners in pharmaceutical R\&D. International Journal of Production Research, 48(24), 7483-7506.

Davis, D. R., \& Mishra, P. (2007). Stolper-Samuelson is dead: And other crimes of both theory and data. In Globalization and poverty (pp. 87-108). University of Chicago Press https://doi.org/10.7208/chicago/9780226318004.003.0003

De Santis, R. A. (2003). Wage inequality in the United Kingdom: trade and/or technology? The World Economy, 26(6), 893-909. https://doi.org/10.1111/1467-9701.00553

Dekkers, R. (2000). Decision models for outsourcing and core competencies in manufacturing. International Journal of Production Research, 38(17), 4085-4096. https://doi.org/10.1080/00207540050204948

Dyer, J. H., \& Ouchi, W. G. (1993). Japanese-Style Partnerships: Giving Companies a Competitive Edge. MIT Sloan Management Review, 35(1), 51.

Egger, H., \& Kreickemeier, U. (2008). International fragmentation: Boon or bane for domestic employment?. European Economic Review, 52(1), 116-132. https://doi.org/10.1016/j.euroecorev.2007.01.006

Egger, P., \& Stehrer, R. (2003). International outsourcing and the skill-specific wage bill in eastern Europe. The world economy, 26(1), 61-72. https://doi.org/10.1080/09535314.2010.493504

Engel, C. (1994). Can the Markov switching model forecast exchange rates? Journal of International Economics, 36(1-2), 151-165. https://doi.org/10.1016/0022-1996(94)90062-0

Falk, M., \& Koebel, B. M. (2002). Outsourcing, Imports and Labour Demand. Scandinavian Journal of Economics, 104(4), 567-586. https://doi.org/10.1111/1467-9442.00302

Falk, M., \& Wolfmayr, Y. (2008). Services and materials outsourcing to low-wage countries and employment: Empirical evidence from EU countries. Structural Change and Economic Dynamics, 19(1), 38-52. https://doi.org/10.1016/j.strueco.2007.12.001

Feenstra, R. C. (1998). Integration of trade and disintegration of production in the global economy. The Journal of Economic Perspectives, 12(4), 31-50. https://doi.org/10.1257/jep.12.4.31

Feenstra, R., \& Hanson, G. (1996). Globalization, Outsourcing, and Wage Inequality. The American Economic Review, 86(2), 240-245. Retrieved from http://www.jstor.org/stable/2118130

Geishecker, I. (2008). The impact of international outsourcing on individual employment security: A micro-level analysis. Labour Economics, 15(3), 291-314. https://doi.org/10.1016/j.labeco.2007.06.015

Geishecker, I., \& Görg, H. (2008). Winners and losers: A micro-level analysis of international outsourcing and wages. Canadian Journal of Economics, 41(1), 243-270. https://doi.org/10.1111/j.1365-2966.2008.00462.x

Gilley, K. M., \& Rasheed, A. (2000). Making More by Doing Less: An Analysis of Outsourcing and its Effects on Firm Performance. Journal of Management, 26(4), 763-790. https://doi.org/10.1177/014920630002600408

Glass, A. J., \& Saggi, K. (2001). Innovation and wage effects of international outsourcing. European Economic Review, 45(1), 67-86. https://doi.org/10.1016/s0014-2921(99)00011-2

Hamilton, J. D. (1989). A new approach to the economic analysis of nonstationary time series and the business cycle. Econometrica: Journal of the Econometric Society, 357-384. https://doi.org/10.2307/1912559

Hansen, B. E. (1992). The likelihood ratio test under nonstandard conditions: Testing the Markov switching model of GNP. Journal of applied Econometrics, 7(S1). https://doi.org/10.1002/jae.3950070506

Hijzen, A. (2007). International outsourcing, technological change, and wage inequality. Review of International Economics, 15(1), 188-205. https://doi.org/10.1111/j.1467-9396.2006.00623.x

Hijzen, A., Gorg, H., \& Hine, R. C. (2005). International Outsourcing and the Skill Structure of Labour Demand in the United Kingdom. The Economic Journal, 115(506), 860-878. https://doi.org/10.1111/j.1468-0297.2005.01022.x 
Holl, A., Pardo, R., \& Rama, R. (2010). Just-in-time manufacturing systems, subcontracting and geographic proximity. Regional Studies, 44(5), 519-533. https://doi.org/10.1080/00343400902821626

Hoon, H. T., \& Ho, K. W. (2001). The Changing Pattern of Production Fragmentation in Singapore and its Economic Consequences. Global Production and Trade in East Asia, 325-345. https://doi.org/10.1007/978-1-4615-1625-5_20

Houseman, S. (2007). Outsourcing, offshoring and productivity measurement in United States manufacturing. International Labour Review, 146(1-2), 61-80. https://doi.org/10.1111/j.1564-913x.2007.tb00044.x

Hsieh, C. T., \& Woo, K. T. (2005). The impact of outsourcing to China on Hong Kong's labor market. The American Economic Review, 95(5), 1673-1687. https://doi.org/10.1257/000282805775014272

Ito, K., \& Fukao, K. (2005). The Vertical Division of Labor and Japanese Outward FDI-Impacts on Human Capital Deepening in Japan. Economic Review, 56(4), 331-347.

Jerzmanowski, M. (2006). Empirics of hills, plateaus, mountains and plains: A Markov-switching approach to growth. Journal of Development Economics, 81(2), 357-385. https://doi.org/10.1016/j.jdeveco.2005.05.005

Katz, L. F., \& Murphy, K. M. (1992). Changes in relative wages, 1963-1987: Supply and demand factors. The Quarterly Journal of Economics, 107(1), 35-78. https://doi.org/10.2307/2118323

Krolzig, H. M., Marcellino, M., \& Mizon, G. E. (2002). A Markov-switching vector equilibrium correction model of the UK labour market. Empirical Economics, 27(2), 233-254. https://doi.org/10.1007/s001810100117

Kumar, S., Zampogna, P., \& Nansen, J. (2010). A closed loop outsourcing decision model for developing effective manufacturing strategy. International Journal of Production Research, 48(7), 1873-1900. https://doi.org/10.1080/00207540802680542

Lloyd, P. J., \& Sandilands, R. J. (1986). The trade sector in a very open re-export economy. Singapore: Resources and Growth.

McCulloch, R. E., \& Tsay, R. S. (1994). Statistical analysis of economic time series via Markov switching $\begin{array}{lllll}\text { models. Journal of Time } & \text { 523-539. }\end{array}$ https://doi.org/10.1111/j.1467-9892.1994.tb00208.x

Mincer, J. A. (1974). Schooling, Experience, and Earnings. In C. Brown, \& M. James (Eds.), The Employer Size-Wage Effect.New York: NBER Press. Journal of Political Economy, 97, 1027-1059. https://doi.org/10.1086/261642

Munch, J. R., \& Skaksen, J. R. (2005). Specialization, outsourcing and wages. IZA Discussion Paper No. 1907.

Rigby, D., \& Breau, S. (2008). Impacts of trade on wage inequality in Los Angeles: Analysis using matched employer-employee data. Annals of the Association of American Geographers, 98(4), 920-940. https://doi.org/10.1080/00045600802219786

Robinson, S., \& Thierfelder, K. (2002). Trade liberalisation and regional integration: The search for large numbers. Australian Journal of Agricultural and Resource Economics, 46(4), 585-604. https://doi.org/10.1111/1467-8489.t01-1-00057

Schmidt, C. M., \& Zimmermann, K. F. (1991). Work Characteristics, Firm Size and Wages. The Review of Economics and Statistics, 73(4), 705. https://doi.org/10.2307/2109410

Simon, J. (1996). A Markov-switching model of inflation in Australia (No. rdp9611). Reserve Bank of Australia.

Thangavelu, S. M., Toh, M. H., \& Ng, K. K. (2008). Outsourcing and fragmentation in Singapore's manufacturing industry. The Singapore Economic Review, 53(03), 539-557. https://doi.org/10.1142/s0217590808003099

Tokarick, S. (2005). Quantifying the impact of trade on wages: The role of nontraded goods. Review of International Economics, 13(5), 841-860. https://doi.org/10.1111/j.1467-9396.2005.00540.x

Tyers, R., \& Yang, Y. (1997). Trade with Asia and skill upgrading: Effects on labor markets in the older industrial countries. Review of World Economics, 133(3), 383-418. https://doi.org/10.1007/bf02707496

Winchester, N. (2008). Searching for the smoking gun: Did trade hurt unskilled workers? Economic Record, 84(265), 141-156. https://doi.org/10.1111/j.1475-4932.2008.00459.x

Wood, A. (1995). How trade hurt unskilled workers. The Journal of Economic Perspectives, 9(3), 57-80. 
https://doi.org/10.1257/jep.9.3.57

Zivot, E., \& Wang, J. (2006). Modelling financial time series with S-Plus (pp. 429-478). Springer. https://doi.org/10.1007/978-0-387-21763-5

\section{Notes}

Note 1. The Correlation integral defined in Grassberger and Procaccia (1983), Characterization of strange attractors. Phys. Rev. Lett., 50(5), pp. 346-349.

Note 2. A Kolmogorov-Smirnov test is performed to examine the differences between the cumulative probability distribution functions of the given data and a Gaussian normal distribution. This is referred to as "Test for non-normal-distributed data".

Note 3. Singapore Standard Occupational Classification.

Note 4.We avoid using data post 2007 for the key reason that post global financial crisis in 2008-09, the Singapore trade economy had consolidated its position in the economic development and trade indicators - and thus the learnings of the development curve of this trade-driven growth economy could be lost (see, for example, the Global Enabling Trade Reports of 2008, 2010 and 2014 by the World Economic Forum - wherein Singapore has been consistently ranked \# 1 for all the three reports).

\section{Copyrights}

Copyright for this article is retained by the author(s), with first publication rights granted to the journal.

This is an open-access article distributed under the terms and conditions of the Creative Commons Attribution license (http://creativecommons.org/licenses/by/4.0/). 